\title{
Mapping the Form and Pattern of Stakeholders' Response towards CSR Program: A Study at PT. Antam Tbk.
}

\author{
Muhammad Ihsan Mattalitti ${ }^{1}$ \\ \{mi_mattalitti@yahoo.co.id ${ }^{1}$ \} \\ Universitas Muhammadiyah Kendari ${ }^{1}$
}

\begin{abstract}
This article reports on findings of a qualitative investigation into the form and the pattern of stakeholders' responses towards PT. Antam's Corporate Social Responsibility (CSR) program. Drawn on the framework of corporate social responsibility, social change and social actions, the results this descriptive study indicated that CSR program in PT. Antam has been intensively implemented since the early 2000s. In 2008, there was a shift of paradigm with regard to program implementation. There have been many social actions performed by the stakeholders ever since the implementation of the CSR program such as becoming donor to local communities. After this shift of paradigm with the corporation, the CSR program become more systematic based on planned program. In this way, the corporation could consider the result of the study on the surrounding communities for the future program implementation.
\end{abstract}

Keywords: corporate social responsibility, stakeholders of CSR, social change, social action

\section{Introduction}

The demands of the people and the development of democracy and the swift currents of globalization and free markets have led to awareness from the corporate world about the importance of implementing Corporate Social Responsibility [1]. Discourse on corporate social responsibility (CSR) in Indonesia has been of significance since the early 2000s. Its existence is closely related to a series of global economic and political dynamics intertwined social and political atmosphere in Indonesia [2]. Much research was published on the implementation of CSR by extractive industries. For companies focusing on the extractive industry, CSR implementation is forced by its nature in forming risk society both ecologically and socially [3]. Therefore, CSR is viewed as solution to sustainable development around such an industry area [4].

Rule No. 40 Year 2007 about Limited Corporation becomes the key point for companies in Indonesia to reconstruct their social responsibility paradigm. Section 74 verse 1 states each company's responsibility to take care of its social and environmental milieu. PT. Aneka Tambang Tbk. (PT. Antam), as part of state corporation focusing on mining, has been adapting new paradigm of social corporate responsibility through implementing good governance, restructuring its management, and improving indicator of performance. Such an improvement aims to lessen the external stakeholders' dependency to the company due to its reactive, charitable, and incidental social program. In general, the external stakeholders consider the company as the solution to their problem. 
CSR's implementation is a dynamic process considering the many parties involved with various interest. Hilson argues that studies on CSR implementation in developing countries are based on factual consideration that the countries are rich with natural resources yet constantly facing management/governance and financial problem as well as having low human development index [5]. Hilson's review on some studies focusing on extractive industry found that the CSR practice in developing countries has been polarized into various debate. Meanwhile, Slack's [6] study revealed that extractive industry's CSR has triggered rhetoric and reality paradox. Also, expected systemic change did not run well due to stakeholders' pressure demanding the company to play its business at one continuum while fulfilling its commitment to the community at the other continuum. Sawedi [7], however, argues that CSR and other forms of company social support have created cultural trap.

This article focuses on the stakeholders' response on corporate social responsibility of PT. Antam before and after its CSR paradigm changed. The paradigm shift would clearly be responded by the stakeholders in many different ways. Therefore, this article aims to map the form and pattern of responses from the stakeholders on PT. Antam's CSR after the shift of the paradigm. Data garnered in a series of observation and in-depth interview were analyzed qualitatively through data reduction, categorization, synthesis, and formulation of working hypothesis.

The demands of the people and the development of democracy and the swift currents of globalization and free markets have led to awareness from the corporation world about the importance of implementing Corporate Social Responsibility [1]. Discourse on corporate social responsibility (CSR) in Indonesia has been of significance since early 2000's. Its existence is closely related to a series of global economic and political dynamic intertwined social and political atmosphere in Indonesia [2]. Much research was published on the implementation of CSR by extractive industries. For companies focusing on extractive industry, CSR implementation is forced by its nature in forming risk society both ecologically and socially [3]. Therefore, CSR is viewed as solution to sustainable development around such an industry area [4].

Rule No. 40 Year 2007 about Limited Corporation becomes the key point for companies in Indonesia to reconstruct their social responsibility paradigm. Section 74 verse 1 states each company's responsibility to take care of its social and environmental milieu. PT. Aneka Tambang Tbk. (PT. Antam), as part of state corporation focusing on mining, has been adapting new paradigm of social corporate responsibility through implementing good governance, restructuring its management, and improving indicator of performance. Such an improvement aims to lessen the external stakeholders' dependency to the company due to its reactive, charitable, and incidental social program. In general, the external stakeholders consider the company as the solution to their problem.

CSR's implementation is a dynamic process considering the many parties involved with various interest. Hilson argues that studies on CSR implementation in developing countries are based on factual consideration that the countries are rich with natural resources yet constantly facing management/governance and financial problem as well as having low human development index [5]. Hilson's review on some studies focusing on extractive industry found that the CSR practice in developing countries has been polarized into various debate. Meanwhile, Slack's [6] study revealed that extractive industry's CSR has triggered rhetoric and reality paradox. Also, expected systemic change did not run well due to stakeholders' pressure demanding the company to play its business at one continuum while fulfilling its commitment to the community at the other continuum. Sawedi [7], however, argues that CSR and other forms of company social support have created cultural trap. 
This article focuses as on the stakeholders' response to the corporate social responsibility of PT. Antam before and after its CSR paradigm changed. The paradigm shift would clearly be responded by the stakeholders in many different ways. Therefore, this article aims to map the form and pattern of responses from the stakeholders on PT. Antam's CSR after the shift of the paradigm. Data garnered in a series of observation and in-depth interviews were analyzed qualitatively through data reduction, categorization, synthesis, and formulation of the working hypothesis.

Consisting of background, literature review (to arrange the state of the art), purpose and problem. Consisting of background, literature review (to arrange the state of the art), purpose and problem formulation.Consisting of background, literature review (to arrange the state of the art), purpose and problem formulation. Consisting of background, literature review (to arrange the state of the art), purpose and problem formulation. Consisting of background, literature review (to arrange the state of the art), purpose and problem formulation. Consisting of background, literature review (to arrange the state of the art), purpose and problem formulation. Consisting of background, literature review (to arrange the state of the art), purpose and problem formulation[8].

\section{Result and Discussion}

\subsection{CSR dan Social Change}

Definition of corporate social responsibility (CSR) is considered complicated because this concept is overlapped with some other concepts such as business ethics, corporate philanthropy, corporate citizenship, sustainable and environmental responsibility [9]. Although there is no single definition, in general, it shares similarities with the company's orientation in generating a profit and providing the community's needs [10]. CSR means the implementation of the company's social responsibility as a business entity. In terms of corporate responsibility, Friedman, as cited by Thomas and Nowak, however, argue that a company only has one responsibility, i.e. making a profit [11], so that the company which has social responsibility is fundamentally diverted from the free market system [12]. In this global trend, such a view has been replaced by the powerful discourse on corporate social responsibility as the business world response to the growth of social and environmental problems. In this way, CSR is also considered as the business contribution to sustainable development focusing on voluntary deeds and implemented within the framework of business and the stakeholders' interaction [13]. CSR is part of company's policy which is implemented professionally and institutionally, involving some program such as community development, social aid, and social advocation as external social service [14].

Based on CSR implementation, there are some categories of companies. Among the categories are related to the company's typology and the direction and objective of its CSR whether aiming for a promotion or community empowerment [15]. 
Company Category based on CSR's Objective

Promotion

\begin{tabular}{|l|l} 
Impressive Company & Progressive Company \\
\hline Passive Company & Agressive Company \\
\hline
\end{tabular}

Empowerment

- The passive company implements CSR aimlessly (not for promotion nor empowerment), but merely charitable action.

- The impressive company implements CSR for promotion rather than empowerment. Such a company tends to create company image than company work.

- The aggressive company implements CSR purely for empowerment rather than promotion. Therefore, this company tends to create company work than company image.

- The progressive company implements CSR to fulfill promotional aim as well as empowerment so that CSR could support the company's success.

The development of CSR discourse has fostered paradigm shift of company's social aid management into social dimension change. In general, social change means the process of structural change in society including mindset, attitude, and behavior as a result of innovation and better life development. In macro level, change takes place at global or state structure involving economic and political aspects. In meso level, change takes place at group, community or organization. Meanwhile, in micro level, change takes place when there is interaction among others. An individual is influenced by structure and institution; social structure and institution are influenced by structure and institution; and social structure and institution are influenced by individual values, beliefs, and attitudes[14].

As a social unit, a company is dynamic and keeps changing in terms of form (structure) and function. It can be seen that different time bears different situation, for example, change in institutional structure or policy. Regarding CSR program implementation, change is marked by the presence of company's social policy orientated to philanthropic activities as its social responsibility. Previously, the company was only responsible to the company's owner in making profit. Recently, in its actual implementation, CSR is no longer considered as philanthropic activities but rather as company's participation in community development and empowerment.

\subsection{CSR Stakeholder dan Social Action}

Responsibility is one of principles in good corporate governance. It highlights the stakeholders' interest; therefore, company should remember the stakeholders' interest and its continuous added value throughout its operation. Along with the development of good corporate governance concept, company is not only responsible to its capital owner, but also to other parties apart from the company.

As Freeman defines, stakeholders are those who influence and being influenced by the company existence [12]. The company entity is closely related to its surrounding; therefore, the company success will be based on the extent to what the company builds good relationship 
and cooperation with its stakeholders. In CSR program, the stakeholders' involvement is varied according to their degree of relevance to the program.

For extractive company, such as nickel mining, neighborhood community and environment become its stakeholders' priority. Both are considered vital because as regards mining industry, they are vulnerable to the impact of mining activities. In addition, the government's involvement as one of stakeholders is also of importance. Therefore, in corporate responsibility implementation, partnership among these three stakeholders will create collaboration and cooperation so that the company needs not to work in solitude, but also involves government as the regulator and community and CSR subject.

Furthermore, stakeholders' involvement in CSR can be viewed from social action perspective. It is assumed that human beings as social creature is inseparable from the existence of others. People will always be in a social life and interact with other people. This social life is run through various forms of individual behavior or social action pattern. Human behavior is a response to or individual reaction towards stimulus of his experience and interaction with his surroundings. Such a response could be passive (without action) in form of thought, opinion or attitude, as well as active response in form of action [16].

From Weber's perspective, social life is seen as a social reality consisting of individuals and their meaningful social actions [17]. Social life is a series of individual actions which take place within the process of being togetherness. Weber argues that social action is individual deed as far as his action has subjective meaning to himself and is directed to others' action [18]. This perspective emphasizes on human subjective aspect with concerns in abstract symptoms such as individual feeling, thoughts and motives.

In order to undertake objective analysis on subjective meanings which underlie individual social actions, Weber coined concept of rational action. Based on the concept, he classifies types of social action [17] as follows:

- Instrumental rational; this action is the highest level of rationality which identifies consideration and conscious calculation in determining target of the action and means used in achieving it. One of forms of this action is economic action within impersonal market system.

- Value rationality; the nature of this rationality is that means are only object of consideration and conscious calculation, while the targets are within its relation with absolute individual values or end value to him.

- Traditional action; this non-rational action is based on orientation to habits, without conscious reflection or plan.

- Affective action; this form of action identifies the action dominated by feeling or emotion without intellectual reflection or conscious plan.

The aforementioned four types of social action reflect a conscious evaluation of action choices. Decision upon form of action is the best way to achieve a target. Weber asserts that an individual undertakes an action based on his experience, perception, understanding, and interpretation of an object stimulus and a certain situation [16].

Therefore, theory of social action emphasizes on the involvement of actor in subjective decision making in order to aim the chosen target as a response to certain stimulus and situation. The actor's involvement is driven by something inside himself in form of freedom of action [18]; and in order to fulfill his social structure interest based on rational calculation [19].

In terms of social action, the stakeholders' involvement in CSR program implementation is marked by a series of interrelated and meaningful action shaped by their response to their 
surrounding phenomena. Therefore, it can be argued that the stakeholders' action is the reflection of the corporate model and approach in CSR program implementation.

\subsection{CSR Paradigm Shift and Stakeholders' Response}

PT. Antam is a state corporate with $65 \%$ government-owned shares and $35 \%$ public-owned shares. This company explores, excavates, and processes several mining reserves such as nickel, bauxite, and gold as primary commodities. PT. Antam was established in 1968 as a merger of seven single commodity mining companies in Indonesia. In the meantime, PT. Antam has business units around the archipelago such as Nickel Ore Mining Business Unit in Pomalaa, Southeast Sulawesi and North Maluku; Gold Mining Business Unit in Pongkor, West Java; Fine Gold Processing and Refinery Business Unit in Jakarta; and Bauxite Mining Business Unit in Bintan Isle, Riau Island.

This article explores PT. Antam's experience in CSR implementation at one of its business units, i.e. Nickel Ore Mining Business Unit in district of Pomalaa, Kolaka Regency of Southeast Sulawesi. In general, Pomalaa district is identified by PT. Antam regarding its 45year operation in this area. It has become inseparable part of the community's life as a result of the longstanding intervening life between community and the company.

\subsection{New Paradigm of PT. Antam's CSR}

There are two conditions triggering the practice of CSR in Indonesia to the least. First, there has been paradigma shift in governance and public policy from government to governance [20]. Second, the locus of political power, which all this time is state-centered, has been distributed to economic institution and civil society. Therefore, social policy, which all this time is deemed as government responsibility, is no longer part of state absolute domain.

The implementation of social responsibility by PT. Antam in Pomalaa is closely related to local community and local government demand on company contribution in developing the area. Community surrounding the mining area is the most risk of social and ecological impact as the excess of mining activities. They demanded the company to compensate many losses they have experienced. Meanwhile, the local government envisaged that the community surrounding the company is still marginalized these 40 years. One of the causes is because PT. Antam as state-owned company prioritizes its responsibility to the central government rather than local.

The beginning of 2000s marked the rise of company philanthropic activities. Activities with similar essence has been operating since 1970s with the most common form conducted by companies in Indonesia through donating to the society. This charitable approach was adhoc, partial and not institutionalized. At this phase, CSR program was only for the sake of doing good and to look good [21]. At the same time, PT. Antam started social aid program as form of its social responsibility. Program implementation which keeps changing eventually brought the company to fundamental change in its CSR program paradigm.

Upon intensive program implementation, PT. Antam's social responsibility is more impressive, a category defining a company's CSR more dominated by promotional motive rather than community empowerment. This can be seen from CSR organizational regulator, where it was first known as community development (Comdev) under Human Relation Department until 2004, but then turned into External Relation Department until 2009. These two departments were responsible for managing company external relationship in order to build communication and company image.

The aforementioned organizational condition is closely related to human resource aspect. Staffs in this department were recruited from other department without considering their 
competence (skill and experience). The staffs were those who were close to retirement. Therefore, when CSR was under Human Relation Department or External Relation Department, it could not be run systematically. Mechanism for program implementation was only based on proposal from outside the company offering incidental and temporary programs. As a newly initiated program, CSR's function was still seen as building good relationship with the community and maintaining company image. While in fact, CSR should have given externality to the community positively. In other words, CSR is an attempt to empower the community in terms of preparing them after mining is over.

Company as a dynamic social system keeps changing on structure and functional aspects influenced by some internal factors and external factors. The mentioned internal factors are 1) trend towards philanthropic attitude of the company; 2) interest on operational legitimation; 3) maintaining company image; and 4) as way to create new investment opportunity for the company. For the natural resources extraction-based company, the interest lies on contribution to surrounding community, also for maintaining the company's existence and sustainability. Meanwhile, external factors which could influence the company are: 1) global force which fostered standardization of good corporate governance; 2) fulfilling national level rules; and 3) fulfilling marginalized local community needs.

Both factors have triggered important changes in CSR implementation at PT. Antam. The first change was organizational restructuring started from commissioner and director levels. CSR, Environment and Post-Mining Committee was added at commissioner level. This committee is responsible to help Commissioner Board by giving professional and independent opinion in order to ensure CSR program implementation, environmental management, and proper post-mining handling based on good corporate governance dan good mining practices. At director level, one specific directorate was added, i.e. General and CSR Directorate. It is responsible to manage strategy, policy, and program on general affairs and CSR, starting from CSR planning, coordination, and implementation and post-mining as well as building good relationship with stakeholders. Meanwhile, at business unit level, Comdev Division under External Relation Department became Comdev Department, which turned into CSR Department in 2010.

The other change was on CSR systematic work mechanism arranged in a 'master plan'. Before the change took place, PT. Antam's social aid activities were conducted without exact guideline towards systematic and measurable program. In this master plan, the company's CSR program was divided into two (see Fig. 2), i.e. primary and secondary program. Primary program is written in the master plan and has long-term target in empowering community and has $75 \%$ of yearly CSR budget. Meanwhile, secondary program is aimed as supplementary program with smaller budget covering only $25 \%$ due to its incidental and temporary nature.

Fig. 1. PT. Antam's CSR Program Schema after Paradigm Shift

\begin{tabular}{|c|c|c|c|}
\hline $\begin{array}{l}\text { Secondary } \\
\text { Program }\end{array}$ & \multicolumn{2}{|c|}{$\begin{array}{l}\text { PT. Antam's } \\
\text { CSR Program }\end{array}$} & $\begin{array}{l}\text { Primary } \\
\text { Program }\end{array}$ \\
\hline \multicolumn{2}{|c|}{$\begin{array}{l}\text { - Unplanned } \\
\text { - Charitable (donation) } \\
\text { - Based on } \\
\text { community/government } \\
\text { proposal } \\
\text { - Covering } 25 \% \text { of yearly } \\
\text { budget }\end{array}$} & \multicolumn{2}{|c|}{$\begin{array}{l}\text { - Planned } \\
\text { - Based on community } \\
\text { empowerment } \\
\text { - Based on Master Plan } \\
\text { - Covering } 75 \% \text { of yearly } \\
\text { budget }\end{array}$} \\
\hline
\end{tabular}


Focusing on community empowerment, PT. Antam runs its CSR program using partnership model with other institutions apart from the company. Due to scarcity in CSR human resources, and as a state-owned corporate, PT. Antam should obey the rule which forbids foundation establishment as company prolongation in CSR program implementation. As a consequence, the company established partnership with non-governmental organization (NGO) and higher education institutions which are competent and rich with relevant skill and experience on planned CSR program.

\subsection{Stakeholders' Response: Dependency Practice and Social Envy}

The stakeholders' involvement plays vital role in influencing CSR program success to some extent. First, stakeholders are influential and being influenced party by the company existence, including this CSR program. Second, CSR program orientated to community empowerment is not the company's primary competence. The company needs partner to run this program, in this case stakeholders consisted of community as CSR subject, government as regulator, and NGO as development agent. Third, democratization process has enhanced community awareness on their participation in development activities. Besides driven by company's need, the stakeholders' involvement in CSR program is also driven by their demand on their involvement in CSR program. Their involvement brings CSR implementation in social niche where the government, company, and community with their own interest are synchronized, making the actors' relationship more dynamic [22].

Stakeholders are actors who playing role and acting out as active response to various experience and interaction with their surroundings [16]. Social action theory emphasizes that the actor is involved in subjective decision making to achieve chosen target as a response to a certain stimulus or situation. An individual's involvement as actor is driven by something inside himself such as freedom of action [18]. This view highlights human being's subjective aspect concerning on abstract symptoms such as individual feeling, thoughts, and motives. In PT. Antam's CSR implementation case, the stakeholders' involvement has existed since the program begun with comdev until the paradigm shift-based CSR program. This condition exposed different experience to the stakeholders and will create different response dynamic. Response to CSR can be seen from their perception and attitude based on the time of implementation of CSR program, before and after the paradigm shift. Before the paradigm shift, the stakeholders' response pattern indicated high dependency; while after the paradigm shift, their response revealed social envy especially from government staff at district level and local NGO. Regarding dependency, all stakeholders-government, community, or local NGO, experienced it. Each stakeholder evaluated CSR program in rational way.

As for local government, ever since the implementation of regional autonomy, they are challenged with optimizing their resources in order to run regional development. The presence of companies in extractive industry is considered potential to support regional development. The government's income is from tax and retribution. The rise of CSR discourse is seen as opportunity to gain financial source for development due to limited budget from government. Government at regency, district, and village levels around the mining area take the practice of asking for aid from the company to support regional development for granted. The village government dependency on PT. Antam existed due to limited allocated budget from district government who assumed that those villages around mining areas get aid from several companies, especially from PT. Antam. To make it worse, the government demand is often driven by subjective motive of the staffs for their personal interest, which they call as 'honorarium' for every infrastructural activity or aid. 
Charitable CSR gives wide impact to community. The company social aid which places community only as object and beneficiary of the program has made the community always hope for the company help on each need or problem they face. Obviously, this is contrast to the essence of CSR to improve social condition of the community highlighting on community development and empowerment. CSR program is supposed to create active involvement of the community rather than passive program beneficiary.

Community attitude which is dependent on company courtesy is constructed by the view that community as native should get beneficiary from their surrounding natural resources. Besides, PT. Antam is seen as a business entity with huge financial resources. Enforced by various environmental problems caused by mining activities affecting community life, CSR is then perceived as company compensation obliged to pay the community as a responsibility for negative impact of its mining activity. Upon this condition, many people often run demonstration so that their request is fulfilled.

Similar to government and community, local NGO also relies on PT. Antam. The presence of NGO in extractive industry has significant meaning, both as controlling power over mining activities which most of the time become the source of problem for the community, and company partner in CSR program implementation, especially community empowerment. The relationship between local NGO with PT. Antam is dynamic. NGO lokal often times pressured the company with many issues, such as environmental, human resource, and good and service provision problem. Their intention is varied, ranging from advocating affected community rights or interest, or demanding work opportunity for local community, as well as environmental and social problems. However, ever since PT. Antam implemented CSR program intensively, local NGO' attention was directed to program control. Some NGOs have become partner in CSR program implementation, especially relevant to environmental activities. Like service provider company, they proposed program to the company, and often times along with pressures using environmental issues.

Social change perspective explains besides resulting in different condition to previous one, a change will also be followed by other changes. Paradigm shift on PT. Antam' CSR management has changed the stakeholders' response. Its paradigm shift is in form and mechanism of program management focusing on community empowerment-based activities. In order to ensure program target achievement, the company chose to involve competent and experienced NGO from outside of Southeast Sulawesi to facilitate the activities. At the beginning of community empowerment program implementation, PT. Antam Pomalaa conducted two programs at the same time, i.e. System of Rice Intensification (SRI), and Revitalization of Bajau Hakatutobu Community Culture (RBHCC). SRI was an activity empowering farmers through agricultural system change from conventional to organic agriculture. Meanwhile, RHCC was aimed improve Bajau community life at Hakatutobu Village using cultural approach as entrance.

Stakeholders' change of response is marked by the social envy phenomena of NGO from outside the region to facilitate PT. Antam's CSR program. Moreover, the community argue that such an empowerment program tends to divide the community between supporting and refusing the program, though not causing social conflict. The presence of such an NGO as facilitator has triggered social envy to agricultural mentor and local NGO. Both the mentor and NGO asked to be involved in PT. Antam's empowerment program regarding that SRI target is closely related to the agricultural mentor's duty, while local NGO assumes that this is the time for them to learn experienced NGO's best practices. This intention was accommodated by the program liaison by inviting the mentors and NGO in empowerment activities. However, such an involvement was insufficient for the mentors and NGO because it 
was contrary to their interest. They asked for similar right to the invited NGO through formal appointment from the company. Besides, they also demanded for incentive of per diem as the facilitator got.

In the mean time, community response was to the contrary. As direct beneficiary of the CSR program, they did not complain the invited NGO as facilitator. Their response tended not to change; they focused on the extent to what the benefit has impact on them. However, there was pro and contra to the program implementation. Those who were for the program revealed their positive perception, regarded the empowerment program beneficial and needed by the community. On the contrary, those who were against the program were dominated by instantthinking oriented community that social aid should be directly distributed and oriented to physical material such as infrastructure. Such a community viewed CSR program focusing on cultural-based empowerment, mindset and attitude change negatively. They even do not want to acknowledge such a program.

\section{Conclusion}

The Based on the discussion in this article, it can be concluded that CSR has been accepted by Indonesian company such as PT. Antam Tbk. as part of its CSR commitment towards community surrounding the mining area. This acceptance is based on the company awareness as a business entity on dynamic developing outside the company at global, national, and local levels. The commitment implementation was in form of fundamental change on CSR paradigm through CSR Master Plan in order to run systematic, directed, and measurable program based on community empowerment.

As a new company policy, its implementation emphasizing on community empowerment program was not fully welcomed by the stakeholders. Dependency on the company has been practiced for a long time and such a paradigm shift has triggered social envy among stakeholders, in this case agriculture mentors and local NGO towards the presence of invited NGO as program facilitator. Moreover, the empowerment program tends to create for and against perception and attitude among the community as program beneficiary.

\section{References}

[1] A. Haris, A. Adys, and A. Prianto, "Pengelolaan Corporate Social Responsibility PT. Lonsum di Kecamatan Ujung Loe Kabupaten Bulukumba," Otoritas J. Ilmu Pemerintah., vol. 4, no. 1, 2014.

[2] S. et. al. Sukada, CSR for Better Life: Indonesian Context, Membumikan Bisnis Berkelanjutan, Memahami Konsep dan Praktik Tanggung Jawab Sosial Perusahaan. Jakarta: ID, Indonesia Business Link, 2007.

[3] A. Upe, "Masyarakat Risiko dalam Lingkar Eksploitasi Pertambangan Emas dan Realisasi CSR di Kabupaten Bombana,” Societal, vol. 1, no. 1, p. 23-33., 2014.

[4] Ilham, "Model Keseimbangan Kawasan Berkelanjutan (Studi: Kawasan Pertambangan dan Industri Nikel di Pomalaa Provinsi Sulawesi Tenggara)," in Disertasi, Program Studi Ilmu Lingkungan, 2018.

[5] G. Hilson, "Social Responsibility in the Extractive Industries: Experiences from Developing Countries," Resour. Policy., vol. 37, pp. 131-137, 2012.

[6] K. Slack, "Mission Impossible?: Adopting a CSR-based Business Model for Extractive Industries in Developing Countries," Resour. Policy, vol. 37, pp. 179-184, 2012. 
[7] S. Muhammad, "Gelombang Perlawanan di Tepian Matano: Resistensi Masyarakat Sorowako terhadap PT Inco,”, Makassar ID, Penerbit Ininnawa, ., 2017.

[8] R. Anwar, D. Darmawan, and C. Setiawan, "Kajian Kitab Tafsir dalam Jaringan Pesantren di Jawa Barat," Wawasan J. Ilm. Agama dan Sos. Budaya, vol. 1, no. 1, pp. 56-69, 2016.

[9] D. Matten, J. Moon, and A. et. al. Habisch, "A Conceptual Framework for Understanding CSR," in Corporate Social Responsibiltiy Across Europe, Heidelberg Germany: Springer, 2005.

[10] D. Doane, "Beyond Corporate Social Responsibility: Mnnows Mammoths and Markets," Futures, vol. 37, pp. 215-229, 2005.

[11] G. Thomas and M. Nowak, "Corporae Social Responsibility: A Defenitional," GBS Work. Pap., no. 62, 2006.

[12] I. Wahyudi and B. Azheri, Corporate Social Responsibility: Prinsip, Pengaturan dan Implementasi. Malang: ID, In-Trans Publishing, 2008.

[13] S. et. al. Sukada and E. al. Sarosa, "Selayang Pandang CSR: Ringkasan Membumikan Bisnis Berkelanjuta," in CSR Untuk Penguatan Kohesi Sosial, Jakarta: ID, Indonesia Business Links, 2008.

[14] E. Suharto, "Corporate Social Responsibility: What is and Benefits for Corporate," Majalah Bisnis dan CSR, vol. 1, no. 4, 2008.

[15] P. Sztompka, Sosiologi Perubahan Sosial. Jakarta: ID, Prenada, 2007.

[16] S. Sarwono, Sosiologi Kesehatan: Beberapa Konsep dan Aplikasinya. Yogyakarta: ID, Gadjah Mada University Press, 1997.

[17] D. P. Johnson, Teori Sosiologi Klasik dan Modern I. Jakarta: ID, Gramedia, 1986.

[18] G. Ritzer, Sosiologi Ilmu Pengetahuan Berparadigma Ganda. Jakarta: ID, Rajawali Press, 2003.

[19] S. Usman, Sosiologi: Sejarah, Teori dan Metodologi. Yogyakarta: ID, Pustaka Pelajar, 2012.

[20] E. Suharto, Membangun Masyarakt Memberdayakan Rakyat: Kajian Strategis Pembangunan Kesejahteraan Sosial dan Pekerjaan Sosial. Bandung: ID, Refika Aditama, 2009.

[21] E. Suharto, "Menggagas Standar Audit Program CSR.”.

[22] Suharko and L. et. al. Trijono, "Negara, Pelaku Bisnis, dan Masyarakat Sipil: Studi Kasus Konflik Inti Indorayon Utama," in Potret Retak Nusantara: Studi Kasus Konflik di Indonesia, Yogyakarta: ID, CSPC-UGM, SEA-CSN, SIDA, ., 2004. 